Gelanggang Olahraga: Jurnal Pendidikan Jasmani dan Olahraga

Volume 1, Nomor 2, Januari-Juni 2018

e-ISSN : 2597-6567

p-ISSN : 2614-607X

DOI : https://doi.org/10.31539/jpjo.v1i2.131

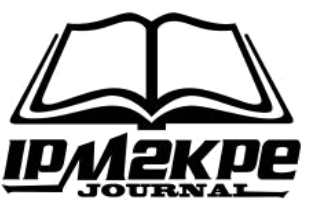

\title{
HUBUNGAN KELINCAHAN DENGAN KEMAMPUAN DRIBBLING PADA SISWA EKSTRAKURIKULER BOLABASKET
}

\author{
Adika Fatahilah \\ STKIP-PGRI Lubuklinggau \\ fatahilah.adika@yahoo.co.id
}

\begin{abstract}
ABSTRAK
Penelitian ini bertujuan untuk mengetahui ada tidaknya hubungan kelincahan dengan kemampuan dribbling. Sampel dalam penelitian ini hanya siswa putra yang berjumlah 20 orang, teknik pengambilan sampel dilakukan dengan purposive sampling. Metode penelitian ini tergolong pada jenis penelitian kuantitatif dengan menggunakan teknik analisis korelasional. Teknik pengumpulan data menggunakan instrumen tes kelincahan Illinois Agility Run Test dan kemampuan dribbling dengan tes kemampuan dribbling bolabasket. Hasil penelitian diperoleh $t_{\text {hitung }}$ lebih besar dari $t_{\text {tabel }}$ atau 3,6977>1,734, sehinggadapat dikemukakan bahwa hipotesis penelitian $\mathrm{H}_{\mathrm{a}}$ diterima dan hipotesis $\mathrm{H}_{0}$ ditolak.. Dapat dilihat dari perhitungan hasil yang menunjukan nilai korelasi ( $\mathrm{r}$ ) dengan ketentuan nilai $\mathrm{r}=$ 0,657 maka koefisien korelasi tergolong kuat. Hasil nilai koefisien diterminan menunjukan variabel bebas kelincahan memberikan kontribusi terhadap kemampuan dribbling bolabasket sebesar 43,16 \% dan sisanya 56,84\% detentukan oleh variabel lain.
\end{abstract}

Kata Kunci: Kelincahan, Kemampuan Dribbling

\begin{abstract}
This study aims to determine the presence or absence of agility relationship with dribbling ability. Samples in this study only male students amounted to 20 people, the sampling technique is done by purposive sampling. This research method pertained to the type of quantitative research by using correlational analysis techniques. The data collection technique uses the Illinois Agility Run agility test instrument and dribbling ability with a dribbling bolabasket ability test. The results obtained tcount greater than ttable or 3.6977>1.734, so it can be said that the hypothesis $\mathrm{Ha}$ accepted research and hypothesis $\mathrm{HO}$ rejected .. Can be seen from the calculation of results that show the value of correlation $(r)$ with the provision value $r=0.657$ then the correlation coefficient pertained strong. The result of coefficient value showed that the variables of free agility contribute to the ability of dribblingbolabasket of $43.16 \%$ and the remaining $56.84 \%$ is determined by other variables
\end{abstract}

Keywords: Agility, Dribbling Capability 


\section{PENDAHULUAN}

Olahraga merupakan aktivitas penting yang harus dilakukan oleh manusia dalam rangka untuk memperoleh kesehatan tubuh, ada banyak jenis cabang olahraga yang ada di dunia salah satunya adalah bolabasket, bolabasket merupakan salah satu cabang olahraga permainan bola besar yang di mainkan oleh dua regu masing-masing regu terdiri dari lima orang, olahraga ini sangat populer dan disukai banyak orang, permainan olahraga bolabasket sudah berkembang menjadi olahraga yang sangat digemari oleh semua lapisan masyarakat, dari anak-anak sampai orang tua, laki-laki maupun perempuan, masyarakat kota sampai masyarakat desamelalui kegiatan permainan olahraga bolabasket banyak manfaat yang diperoleh, khususnya dalam hal pertumbuhan fisik, mental dan sosial yang baik. Salah satu bentuk tujuan olahraga bolabasket adalah pencapaian prestasi maksimal yang juga tak luput dari perhatian pemerintah dalam pengembangan olahraga prestasi. Bentuk perhatian pemerintah dalam pengembangan olahraga prestasi di Indonesia telah dijabarkan dalam Undang-Undang Republik Indonesia No. 3 tahun 2005 tentang Sistem Keolahragaan Nasional, dalam pasal 20 ayat 2 dan 3 menjelaskan bahwa:

Olahraga prestasi dilakukan oleh setiap orang yang memiliki bakat, kemampuan dan potensi untuk mencapai prestasi. Olahraga prestasi dilaksanakan melalui pembinaan dan pengembangan secara terencana, berjenjang dan berkelanjutan dengan dukungan ilmu pengetahuan dan teknologi keolahragaan.

Dalam pencapaian prestasi olahraga bolabasket di Indonesia harus didukung oleh pembinaan dan pengembangan secara terencana, berjenjang dan berkelanjutan dengan dukungan ilmu pengetahuan dan teknologi keolahragaan.Di samping itu, dibutuhkan bakat kemampuan dan potensi untuk mencapai prestasi. Sehubungan dengan ini Syafruddin (2013) mengemukakan:

Ada dua faktor yang mempengaruhi dalam mencapai prestasi, faktor tersebut adalah faktor internal dan faktor eksternal. Faktor internal adalah faktor yang timbul dari dalam diri atlet seperti kondisi fisik, teknik, taktik, mental (psikis), sedangkan faktor eksternal adalah faktor yang datang dari atas diri atlet seperti sarana dan prasarana, pelatih, pembina, keluarga, organisasi, dana, iklim, makanan yang bergizi dan banyak lagi yang lainnya.

Pendapat di atas mengemukakan bahwa dalam prestasi olahraga bolabasket, sebenarnya banyak faktor yang mempengaruhi, khususnya faktor fisik dan teknik.Tujuan dari permainan bolabasket adalah memasukkan bola ke basket lawan dan berusaha mencegah lawan memasukkan bola atau mencetak angka.Berdasarkan tujuan tersebut salah satu teknik dasar yang sangat penting untuk dikuasai yaitu teknik dribbling.Dribbling merupakan kemampuan siswa memindahkan bola menggunakan tangan dengan secepat-cepatnya untuk pencapaian tujuan yaitu mengadakan serangan balik, melewati lawan, memancing lawan, mengatur tempo permainan serta mencetak angka ke basket lawan secara efektif dan efisien tanpa kehilangan keseimbangan.Melalui dribbling yang benar 
diharapkan setiap pemain memiliki kemampuan yang baik dalam bermain bolabasket.

Pada hakikatnya setiap pemain bolabasket dituntut agar mampu melakukan dribbling yang baik, lincah tanpa kehilangan keseimbangan ketika melewati setiap lawan. Pada perkembangan bolabasket modern saat ini dribbling sangat bervariatif seperti: a) dribble passing dan lay-up, b) change of pace dribble, c) retreat dribble, d) crossover dribble, d) inside-out dribble, e) reserve dribble, dan f) dribble lay-up (Oliver, 2009)

Di samping itu, dribblingberperan penting dalam permainan bolabasket untuk menunjang teknik dasar seperti shooting dan passing, dalam permainan bolabasket shooting dan passing di area lawan yang kosong tanpa penjagaan yang ketat dari lawan untuk melakukan shooting ke basket lawan untuk menghasilkan angka dapat dibangun dari kemampuan dribblingdengan begitu permainan bolabasket lebih variatif dan semangat bermain akan bertambah. Menurut Oliver (2009) untuk memperoleh hasil dribbling yang diinginkan sesuai dengan kebutuhannya dalam bermain bola basket dipengaruhi oleh faktor bakat dan kemauan, kekuatan otot tungkai, kecepatan, kelentukan, keseimbangan dan kelincahan.

Bakat dan kemauan merupakan potensi yang dimiliki siswa semenjak lahirdan merupakan daya tangkap siwa secara afektif untuk mempelajari dribbling dengan baik.Apabila bakat dan kemauan baik, maka siswa dapat melakukan dribbling bola dengan baik.Selain itu faktor yang harus dimiliki siswa untuk mendukung diribling yang baik adalah kekuatan otot tungkai dibutuhkan untuk dapat kuat berlari. Apabila kekuatan otot tungkai siswa lemah, maka ssiswaakan kesulitan melakukan dribbling dengan baik dan bola mudah terlepas dari penguasaan siswa, selain itu kecepatan dibutuhkan untuk berlari sambildribbling bola secara cepat. Apabila siswa tidak memiliki unsur kecepatan, maka siswa akan kesulitan melakukan dribbling dan gerakan dribbling bola dapat dengan mudah dibaca oleh lawan serta bola mudah dirampas dari tangan siswa, tidak hanya kecepatan yang harus dimiliki kelentukanjuga dibutuhkan sebagaiperluasan ruang gerak sendi. Apabila tingkat kelentukan yang dimiliki siswa tinggi, maka akan dapat mengefisienkan gerakan, mengefektifkan waktu dan energi di saat dribbling, untuk itu keseimbanganjuga dibutuhkan pada saat berlari dengan cepat sambil dribbling bola. Apabila keseimbangan tubuh rendah, maka pada saat dribbling, siswa akan dapat terjatuh dan bola terlepas dari penguasaan, menyempurnakan gerakan tersebut yakni kelincahan dibutuhkan saat dribbling bola agar dapat selalu berpindah tempat sesuai dengan situasi dan kondisi yang dihadapi siswa. Apabila siswa tidak memiliki kelincahan, akan kesulitandribbling dengan berpindah arah ataupun tempat.

Faktor-faktor tersebut sangat berkaitan untuk mendukung kemampuan dribbling bolabasket yang baik. Selain beberapa faktor di atas, faktor eksternal yang juga ikut mempengaruhi hasil dribbling seorang atlet bolabasket adalah sarana dan prasarana.Sarana dan prasarana permainan bolabasket diharapkan harus memenuhi standar yang disarankan dalam peraturan yang diberikan PERBASI. Sarana dan prasarana yang tidak memenuhi standar seperti: lapangan yang berlubang, lantainya tidak datar dan permukaannya licin, tidak akan dapat menghasilkan kemampuan dribbling yang baik. 
Dalam hal ini permasalahan diduga terjadi pada siswa ekstrakurikuler bolabasket SMA Negeri 19 Palembang Tahun Pelajaran 2013/2014.Permasalahannya adalah diduga masih rendahnya kemampuan dribbling siswa dalam permainan bolabasket. Siswa SMA Negeri 19 Palembang melakukan aktivitas latihan di lapangan bola basket sekolah dengan jadwal latihan rutin tiga kali seminggu yaitu hari Selasa, Kamis dan Minggu.

Rendahnya kemampuan dribbling siswa dalam bermain bola basket telihat pada setiap ada kesempatan dribbling, banyak siswa yang gagal.Kegagalan siswa dribbling bola dalam permainan bolabasket disebabkan pemain tidak mampu dribbling bola dengan baik. Bola cenderung lepas dari penguasaan dan mudah dirampas lawan.Pemain tidak dapat dribbling sambil berlari dengan lincah melewati lawan saat melakukanserangan balik, akibatnya pemain lawan sudah terlebih dahulu kembali ke daerah pertahanannya untuk menghalangi laju pemain.Akibat lambatnya serangan yang dilakukan pada saat dribbling, makabola dapat dengan mudah dirampas oleh lawan, ide permainan bolabasket tidak berjalan sesuai tujuan yang diharapkan sehingga menyebabkan kesempatan untuk menyusun serangan dan mencapai kemenangan akan semakin rendah. Dengan demikian, prestasi bolabasket sukar dicapai, Hal ini dibenarkan oleh Oktaprio selaku pelatih yang melatih siswa SMA Negeri 19 Palembang dalam bermain bolabasket.

Rendahnya kemampuan dribbling siswa, akan membawa dampak terhadap keberhasilan tim selama mengikuti kompetisi. Jika fenomena tersebut terus dibiarkan akan berdampak kurang baik untuk kemajuan prestasi siswa SMA Negeri 19 Palembang dalam permainan bolabasket. Diduga faktor kelincahan lebih dominan dalam menentukan kemampuan dribbling bolabasket.Oleh sebab itu, peneliti tertarik untuk melakukan penelitian dengan judul "Hubungan Kelincahan Dengan KemampuanDribbling Pada Siswa Ekstrakurikuler Bolabasket SMA Negeri 19 Palembang”.

\section{KAJIAN TEORI}

Bolabasket pertama kali ditemukan oleh Dr. James Naismith, anggota sekolah pelatihan Young Mans Christian Association (YMCA) di Springfield, Massachusetts pada bulan Desember 1891. Oraganisasi yang melindungi olahraga bolabasket di Indonesia adalah PERBASI (Persatuan Bola Basket Seluruh Indonesia), Organisasi ini di diriakan pada 23 Oktober 1951 dan diresmikan atas prakarsa Ketua KONI (Komite Olahraga Nasional Indonesia) yang saat itu, Maladi (Nugraha, 2010). Bolabasket merupakan permainan bola besar yang dimainkan dua regu yang masing-masing terdiri dari lima orang yang dimana tiaptiap regu berusaha memasukkan bola kedalam ring atau membuat poin, dimana bola dioper (passing), digiring (dribble) atau dipantulkan kesegala arah sesuai dengan peraturan (Kurniawan, 2011).

Gerakan dalam permainan bolabasket terdiri dari gabungan unsur-unsur gerak yang terangkai dengan rapi, sehingga menunjukkan suatu permainan yang meriah. Menurut (Margono, 2010) mengatakan, "tujuan bermain bolabasket adalah untuk mendapat nilai (skor) dengan memasukkan bola ke dalam keranjang lawan dan mencegah tim lawan melakukan hal serupa". 
Dalam permainan bolabasket terdapat banyak gerakan yang harus dilakukan seperti olah kaki, mengoper, menangkap, mengiring, menembak, gerakan tanpa bola, gerakan dengan bola, menyerang dan bertahan. Kemampuan siswa untuk menampilkan berbagai macam gerakan dalam permainan bolabasket sangat bergantung pada penguasaan teknik-teknik dasar yang menunjang permainan ini. Dengan teknik dasar yang baik dan benar, maka efesiensi dan efektifitas gerak akan dicapai yang selanjutnya akan membuahkan kemampuan yang berkualitas. Artinya, permainan bolabasket merupakan olahraga yang memiliki aktivitas gerak yang menuntut berbagai kemampuan, teknik dan taktik untuk mencapai tujuan permainan. Permainan bolabasket adalah olahraga yang berdasarkan kebiasaan, artinya untuk menjadi seorang atlet bolabasket yang baik sangat dibutuhkan proses latihan atau bermain secara berulang-ulang atau berkelanjutan (continue) agar memperoleh teknik, taktik dan kondisi prima dalam permainan yang bagus.

Menurut Kosasih (1993) teknik dasar permainan bolabasket terdiri dari beberapa macam, antara lain sebagai berikut:

1. Mengumpan bola (passing), merupakan teknik permainan bolabasket yang paling mendasar dan esensial dimana gerakannya dilakukan dengan menggunakan satu atau kedua tangan dengan cara mendorong bola, memantulkan ataupun melemparkannya kepada teman bermain sehingga bola dapat berpindah dari suatu tempat ke tempat lain sesuai dengan yang diharapkan dan selalu tepat dalam penguasaan.

2. Menangkap (catching), merupakan satu usaha menerima bola dengan satu tangan atau dengan dua tangan, baik dala keadaan berhenti, berjalan maupun dalam keadaan berlari.

3. Memantul-mantulkan bola (dribbling), merupakan bentuk gerakan membawa bola yang disahkan dalam peraturan dan salah satu teknik membawa bola kesegala arah dengan lebih dari satu langkah dengan syarat bola sambil dipantulkan kelantai dengan salah satu tangan atau berselang seling dengan kedua tanggan. Dribbling juga merupakan salah satu cara untuk mengamankan bola dari rampasan lawan, sebab dengan melakukan dribbling seseorang pemain dapat bergerak menjauh dari lawan sesuai dengan tujuan yang diinginkan.

4. Memasukkan bola atau menembak (shooting), merupakan satu cara untuk memasukkan bola ke dalam keranjang atau basket lawan. Dengan cara menembakkan bola ke keranjang lawan ini, maka nilai atau skor akan diraih. Jadi menembak merupakan sasaran akhir setiap bermain.

5. Berputar/gerakan berporos (pivot), merupakan suatu usaha mengubah arah hadap badan ke segala arah dengan satu kaki tetap tinggal di tempat sebagai poros (as). Kaki yang tetap kontak dengan lantai disebut kaki poros atau pivot. 


\section{METODE PENELITIAN}

Metode penelitian ini tergolong pada jenis metode penelitian kuantitatif dengan menggunakan teknik analisis korelasional.Menurut Margono (2010) mengemukakan bahwa penelitian korelasional bertujuan untuk menemukan ada tidaknya hubungan dan apabila ada, berapa erat hubungan serta berarti atau tidak hubungan itu.

Tempat penelitian adalah di lapangan bolabasket SMA Negeri 19 Palembang. Pada penelitian ini yang dijadikan populasi adalah siswa ekstrakurikuler bolabasket SMA Negeri 19 Palembang yang berjumlah 20 orang putra dan 16 orang putri. Agar lebih jelasnya gambaran populasi penelitian dapat dilihat pada tabel 1 berikut.

Dalam penelitian ini dijadikan sampel penelitian hanya siswa putra yang berjumlah 20 orang, teknik pengambilan sampel dilakukan dengan purposivesampling adalah teknik penentuan sampel dengan dikarenakan dibutuhkan anak-anak yang sudah terampil teknik dasar keterampilan driblingnya. pertimbangan tertentu (Sugiyono, 2013).

Jenis data dalam penelitian ini adalah data primer dan data sekunder.Data primer adalah data yang langsung diambil dari tes dan pengukuran kelincahan dan kemampuan dribblingsiswa ekstrakurikuler bolabasket SMA Negeri 19 Palembang yang terpilih menjadi sampel.Sedangkan data sekunder adalah data yang diperoleh dari dokumen-dokumen yang diberikan oleh pelatih bolabasket yang bersangkutan seperti biodata siswa.

Data yang diperlukan dalam penelitian ini adalah kelincahan dan kemampuan dribbling yang dilakukan siswa ekstrakurikuler bolabasket SMA Negeri 19 Palembang Tahun Pelajaran 2013/2014.Kelincahan dengan Ilinois Agility Run test. Menurut Widiastusti (2011), dan Nurhasan (2001) kemampuan Dribbling dengan tes kemampuan Dribbling bolabaske

\section{HASIL PENELITIAN}

Berdasarkan hasil tes kelincahan, diperoleh skor maksimum adalah 18,62 dan skor minimum 16,05. Di samping itu diperoleh nilai mean (rata-rata) $=$ 17,09, median $=16,85$, modus $=17,75$, Standar Deviasi $=0,79$. Agar lebih jelasnya deskripsi data kelincahan dapat dilihat pada tabel berikut.

Tabel 1

Distribusi Frekuensi Kelincahan (X)

\begin{tabular}{ccccc}
\hline No & $\begin{array}{c}\text { Kelas Interval } \\
(\text { meter })\end{array}$ & $\begin{array}{c}\text { Absolut } \\
(\text { Fa) }\end{array}$ & Relatif $(\%)$ & Kategori \\
\hline 1 & $<15.2$ & 0 & 0 & Baik sekali \\
\hline 2 & $16.1-15.2$ & 2 & 10 & Baik \\
\hline 3 & $18.1-16.2$ & 17 & 85 & Cukup \\
\hline 4 & $18.3-18.2$ & 1 & 5 & Kurang \\
\hline 5 & $>18.3$ & 0 & 0 & Kurang sekali \\
\hline & Jumlah & 20 & 100 & - \\
\hline
\end{tabular}



bawah ini:

Berdasarkan tabel satu di atas, dapat digambarkan melalui histogram di

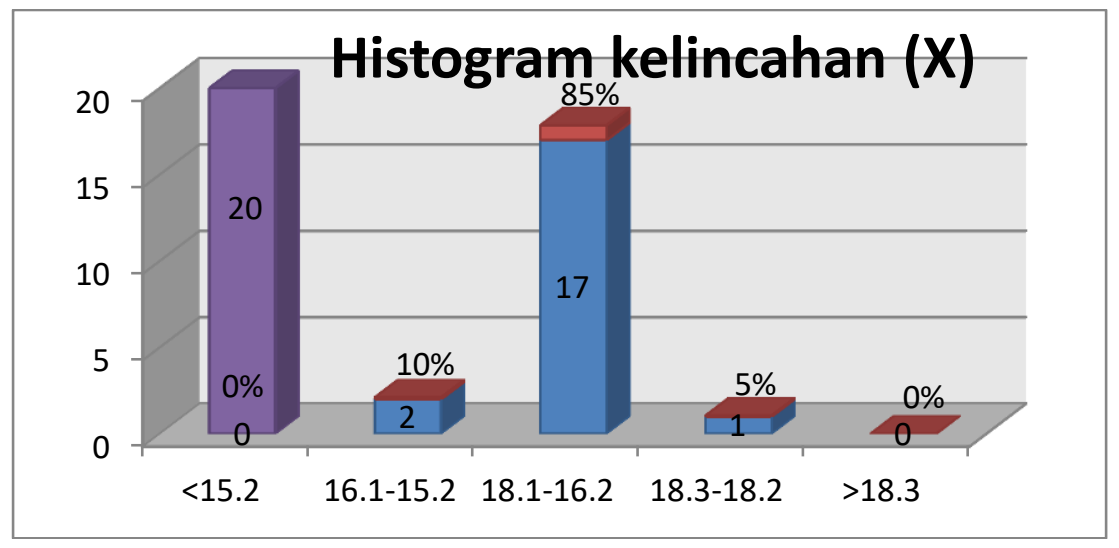

Gambar 1 : Histogram kelincahan (X)

Keterangan :

$$
\begin{aligned}
& \text { Ungu }=\text { Jumlah Sampel } \\
& \text { Biru }=\text { Jumlah Orang }
\end{aligned}
$$

Berdasarkan histogram di atas dari 20 orang sampel, $0 \%$ yang tergolong kategori baik sekali, 2 orang (10\%) mencapai waktu16.1-15.2 tergolong kategori baik, 17 orang (85\%) mencapai waktu18.1-16.2 tergolong kategori cukup, 1 orang (5\%) mencapai waktu18.3-18.2 tergolong kategori kurang dan 0\%yang tergolong kategori kurang sekali.

Berdasarkan hasil tes kemampuan dribbling, diperoleh skor maksimum adalah 15 dan skor minimum 7 di samping itu diperoleh nilai mean (rata-rata) $=$ 11 , median $=11$, modus $=10$, Standar Deviasi $=2,2711$. Agar lebih jelasnya deskripsi data dribling dapat dilihat pada tabel berikut.

Tabel 2

Distribusi Frekuensi Kemampuan Dribbling (X)

\begin{tabular}{ccccc}
\hline No & $\begin{array}{c}\text { Kelas Interval } \\
(\text { meter })\end{array}$ & $\begin{array}{c}\text { Absolut } \\
(\text { Fa) }\end{array}$ & Relatif $(\%)$ & Kategori \\
\hline 1 & $6-7$ & 1 & 5 & Kurang sekali \\
\hline 2 & $8-9$ & 3 & 15 & Kurang \\
\hline 3 & $10-11$ & 10 & 50 & Cukup \\
\hline 4 & $12-13$ & 2 & 10 & Baik \\
\hline 5 & $14-15$ & 4 & 20 & Baik sekali \\
\hline & Jumlah & 20 & 100 & - \\
\hline
\end{tabular}



bawah ini:

Berdasarkan tabel dua di atas, dapat digambarkan melalui histogram di

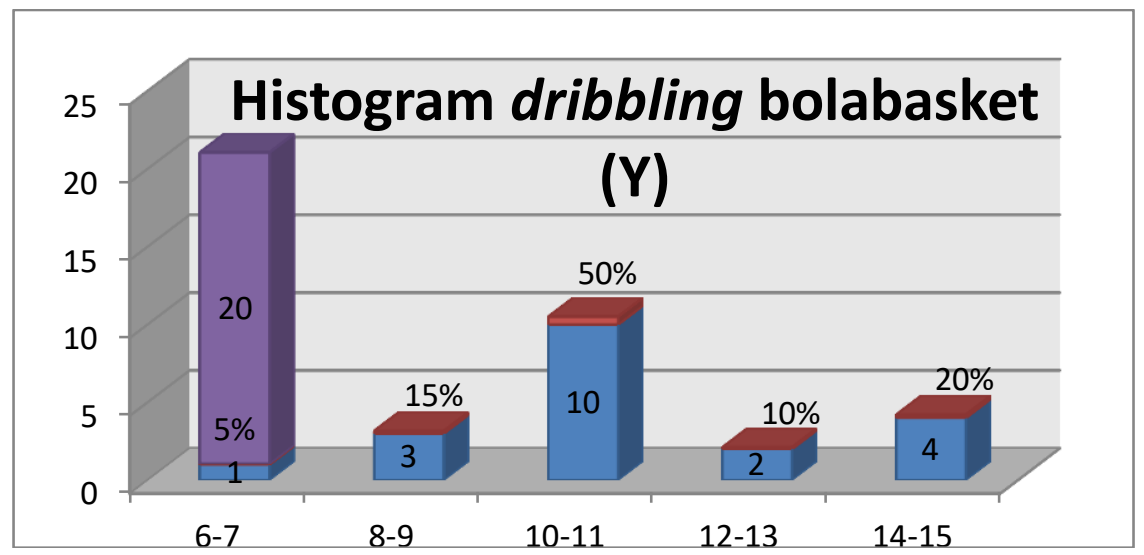

Gambar 2: Histogram kemampuan dribbling bolabasket (Y)

Keterangan :

$$
\begin{aligned}
& \text { Ungu }=\text { jumlah sampel } \\
& \text { Biru }=\text { jumlah orang }
\end{aligned}
$$

Berdasarkan histogram gambar 2 di atas dari 20 orang sampel, 4 orang yang melewati 14-15 rintangan (20\%) yang tergolong kategori baik sekali, 2orang yang melewati 12-13 rintangan (10\%) tergolong kategori baik, 10orang yang melewati 10-11 rintangan (50\%) tergolong kategori cukup, 3orang yang melewati 8-9 rintangan (15\%) tergolong kategori kurang dan 1 orang yang mampu melewati 6-7 rintangan (5\%)yang tergolong kategori kurang sekali.

Uji normalitas bertujuan untuk mengetahui apakah data yang diperoleh berdistribusi normal atau tidak.Uji normalitas distribusi variablekelincahan dan kemampuan dribbling bolabasket. Data tes akhir dianalisis dengan uji Lilliefors, dengan taraf signifikansi yang digunakan sebagai dasar menolak ataupun menerima keputusan normal atau tidaknya suatu distribusi data adalah $\alpha=0,05$.

Tabel 3

Rangkuman Analisis Uji Normalitas

\begin{tabular}{clccc}
\hline No & \multicolumn{1}{c}{ Variabel } & $\mathbf{L}_{\text {hitung }}$ & $\mathbf{L}_{\text {tabel }}$ & Keterangan \\
\hline 1. & Kelincahan $(\mathrm{X})$ & 0.15260 & 0.190 & Normal \\
2. & Kemampuan dribbling bolabasket $(\mathrm{Y})$ & .15 & 0,190 & Normal \\
& & & & \\
\hline
\end{tabular}

Berdasarkan table tiga di atas, kelincahansebagai variabel bebas (X) pada taraf signifikansi 0,05 diperoleh $\mathrm{L}_{\text {hitung }} 0,1526<\mathrm{L}_{\text {tabel }}$ 0,190, dan kemampuan dribbling bolabasket sebagai variabel terikat $(\mathrm{Y})$ diperoleh $\mathrm{L}_{\mathrm{hitung}}$ $0,15<\mathrm{L}_{\text {tabel }} 0,190$ pada taraf signifikansi 0,05. Jika $\mathrm{L}_{\text {hitung }}$ lebih kecil dari $\mathrm{L}_{\text {tabel }}$ berarti populasi berdistribusi normal.Dengan demikian dapat disimpulkan bahwa data dari setiap variabel di atas berdistribusi normal. 
Setelah diperoleh koefisien korelasi diperoleh (r) sebesar 0,6570, jika dilihat dari tabel interpretasi kolerasi nilai (r) maka koefisien korelasi 0,60-0,799 tergolong tingkat hubungan kuat. Adapun tabel interprestasi sebagai berikut :

Tabel 4

Interprestasi Koefisien Korelasi Nilai r

\begin{tabular}{cc}
\hline Interval koefisien & Tingkat hubungan \\
\hline $0,00-0,199$ & Sangat rendah \\
$0,20-0,399$ & Rendah \\
$0,40-0,599$ & Sedang \\
$0,60-0,799$ & Kuat \\
$0,80-1,000$ & Sangat kuat
\end{tabular}

(Sugiyono, 2013).

\section{PEMBAHASAN}

Berdasarkan hasil analisis data diatas telah diperoleh hasil dengan interval koefisien 0,6570 untuk hubungan kelincahan dengan kemampuan dribbling bolabasket, berarti hasil ini menunjukan bahwa kedua variabel tersebut saling berhubungan. Dimana dapat dilihat dari tabel interprestasi koefisien korelasi nilai (r) variabel bebas $(\mathrm{X})$ dan variabel terikat $(\mathrm{Y})$ mempunyai tingkat hubungan kuat.Setelah data dihitung menggunakan rumus korelasi product moment didapatkan hasil 0,6570, kemudian untuk menyatakan besar kecil sumbangan variabel (X) dan (Y) dapat ditentukan dengan rumus diterminan sehingga mendapatkan hasil 43,16\% artinya variabel bebas (X) kelincahan memberikan kontribusi terhadap variabel (Y) kemampuan dribbling bolabasket dan sisanya $56,84 \%$ ditentukan oleh variabel lainseperti kelentukan, kelenturan, kecepatan, keseimbangan dan koordinasi.

Kemudian dilakukan uji hipotesis hasil analisis data yang telah diperoleh dengan $t_{\text {hitung }}>$ lebih besar dari $t_{\text {tabel }}$ atau 3,6977>1,734, sehingga dapat dikemukakan bahwa hipotesis penelitian $\mathrm{H}_{\mathrm{a}}$ diterima dan hipotesis $\mathrm{H}_{0}$ ditolak. Kelincahan merupakan usaha seseorang berlari mengerahkan seluruh kemampuan tubuhnya untuk memberikan kontribusi terhadap kemampuan dribbling bolabasket dalam situasi yang berbeda-beda dan arah yang berubah-ubah secara cepat dengan waktu yang singkat tanpa kehilangan keseimbangan.

\section{SIMPULAN}

Berdasarkan hasil penelitian dapat disimpulkan kelincahan merupakan usaha seseorang berlari mengerahkan seluruh tubuhnya untuk memberikan kontribusi terhadap kemampuan dribbling bolabasket dalam situasi yang berbeda-beda dan arah yang berubah-ubah secara cepat dengan waktu yang singkat tanpa kehilangan keseimbangan. Dengan meningkatkan unsur kelincahan, maka diharapkan pemain bolabasket dapat meningkatkan kemampuan dribbling dengan baik dan cepat serta tanpa kehilangan keseimbangan sesuai tujuan yang diinginkan. Hasil koefisien korelasi (r) diperoleh sebesar 0,6570 tergolong tingkat hubungan kuat, kelincahan berkontribusi terhadap kemampuan dribbling bolabasket siswa dalam ekstrakurikuler bolabasket SMA Negeri 19 Palembang 
Tahun Ajaran 2013/3014 sebesar 43,16 \%artinya variabel bebas (X) kelincahan memberikan kontribusi terhadap variabel (Y) kemampuan dribbling bolabasket dan sisanya 56,84 \% ditentukan oleh variabel lainseperti kelentukan, kelenturan, kecepatan, keseimbangan dan koordinasi.

Hasil analisis data yang telah diperoleh dengan $\mathrm{t}_{\text {hitung }}>$ lebih besar dari $\mathrm{t}_{\text {tabel }}$ atau 3,6977>1,734, sehingga dapat dikemukakan bahwa hipotesis penelitian $\mathrm{H}_{\mathrm{a}}$ diterima dan hipotesis $\mathrm{H}_{0}$ ditolak.Hal ini berarti bahwa apabila kelincahan siswa tinggi, maka kemampuandribbling cenderungtinggi. Sebaliknya, apabila kelincahan siswa rendah, maka kemampuan dribblingsiswa cenderung rendah.

\section{DAFTAR PUSTAKA}

Kosasih, D. (2008). Fundamental Basketball First Step To Win. Semarang : Karangturi Media.

Kurniawan, F. (2011). Buku Pintar Olahraga. Jakarta: Laskar Aksara. Margono, A. (2010). Permainan Bolabasket. Surakarta: UNS press.

Margono. (2010). Metodologi Peneltian. Jakarta: PT Renika Cipta

Nugraha, A., R. (2010). Mengenal Aneka Cabang Olahraga. Bekasi: PT. Cahaya Pustaka Rega.

Nurhasan. (2001). Tes dan Pengukuran dalam Pendidikan Jasmani, prinsipprinsip dan Penerapannya. Jakarta: Direktorat Jenderal Olahraga.

Oliver, J. (2009). Seri Dasar-dasar Olahraga. Dasar-dasar Bola Basket. Cara yang lebih baik untuk mempelajarinya. Bandung: Pakar Raya.

Sugiyono, (2013). MetodePenelitian Pendidikan. Pendekatan Kuantitatif, Kualitatif, dan R\&D. Jakarta: Alfabeta.

Syafruddin. (2013). Ilmu Kepelatihan Olahraga. Teori dan Aplikasinya dalam Pembinaan Olahraga. Padang: FIK UNP.

Undang-undang Republik Indonesia Nomor 3 Tahun 2005. 2009. Tentang Sistem Keolahragaan Nasional. Jakarta: Diperbanyak oleh Biro Humas dan Hukum Kementerian pemuda dan olahraga Republik Indonesia.

Widiastuti. (2011). Tes dan Pengukuran Olahraga. Jakarta: PT Bumi Timur Jaya. 